Annals of Warsaw University of Life Sciences - SGGW

Land Reclamation No 50 (1), 2018: 43-54

(Ann. Warsaw Univ. of Life Sci. - SGGW, Land Reclam. 50 (1), 2018)

\title{
Risk assessment of climate change impacts and the post-mining land reclamation on the example of the "Brzeziny" Natural Aggregate Mine
}

\author{
KATARZYNA PAWEŁCZYK
}

Faculty of Mining and Geoengineering, AGH University of Science and Technology

\begin{abstract}
Risk assessment of climate change impacts and the post-mining land reclamation on the example of the "Brzeziny" Natural Aggregate Mine. Mitigation of climate change and adaptation to its effects manifested in increasingly extreme meteorological phenomena are one of the most important contemporary global challenges. In the face of new hazards, numerous measures are taken to adapt environmental components and ventures to climate change, such as the reclamation of degraded areas - recognized as a key adaptation and mitigation action. The success and the property of selecting these measures, including reclamation, requires a detailed recognition of the risk of occurrence of various hazards and of the severity of their consequences in a given area. The study assessed the risk of the climate change impacts on the post-mining area and based on its results an optimal method of reclamation of the "Brzeziny" gravel pit was proposed, aimed at the maximum adaptation of the area to the occurrence of potential climate events. The risk analysis was based on elements of the common risk assessment methodology (CRAM) and enriched with elements of the analytic hierarchy process method (AHP). Moreover, the event tree analysis (ETA) logic technique was used to assess the proposed adaptation measures at the reclamation stage.
\end{abstract}

Key words: climatic risk assessment, reclamation, post-mining area, adaptation to climate change

\section{INTRODUCTION}

Dangerous meteorological phenomena such as heavy rainfall, floods, heat waves, droughts, wildfires, strong wind etc. being a consequence of observed climate changes, are expected to become more frequent and more violent (MŚ 2013a). In the face of increasing risk, as part of the implementation of climate policy, two types of activities are undertaken - adaptation and mitigation. Adaptation aims to adapt areas and elements sensitive to phenomena resulting from climate change and reduce their negative effects at the local, regional and national level (EC 2016). The mitigation, on the other hand, aims to reduce greenhouse gases emissions, as well as to strengthen their sinks by, for example, the appropriate land use (Füssel 2007) mainly at national and international level. Mitigation measures are an important element of international climate policy and are necessary for effective adaptation activities. Both areas - adaptation and mitigation must be mutually consistent (EC 2007).

An important element in the design of adaptation and mitigation measures is the assessment of the risk of the impact of climate change on the analysed area (Capstick 2016). This risk assessment identifies the level of risk for individual hazards and indicates those for which actions should be taken first. In addition, it allows to designate those elements that are the most vulnerable areas in the context of climate change. 
In the case of post-mining areas, the best moment for implementing measures to adapt such land to climate change is the reclamation stage. The mining entrepreneur is obliged to reclaim the land, transformed as a result of exploitation (Geological and mining law). Act on protection of agricultural and forest land from 2004 defines reclamation as granting or restoring degraded or devastated land utility or natural values by properly shaping the surface, improving physical and chemical properties, regulating water relations, restoring soils, strengthening scarps and rebuilding or building the necessary roads. Reclamation is thus the first stage of the post-mining area repair and prepares it for the final development (Chodak 2013). Therefore, it seems appropriate to include in the design phase of reclamation the risk assessment of the impact of climate change on the post-mining area, which will allow for optimizing reclamation actions and preparing the site for potential extreme meteorological events.

The work involved the risk assessment related to the occurrence of extreme meteorological phenomena, adaptive actions were proposed at the reclamation stage and the analysis of the course of these phenomena was performed after applying the proposed measures.

\section{STUDY AREA}

The assessment of the risk of the impact of climate change manifested in extreme meteorological phenomena has been carried out for the "Brzeziny" Natural Aggregate Mine. Exploitation of the natural aggregate deposit was conducted using the opencast method under the water surface, resulting in a water body with an area of approx. 24 ha.

The study area is located in the Opolskie Voivodeship, Nysa Poviat, Skoroszyce Commune. The area on which the mining plant is located is characterized by flat terrain and agricultural development. In addition to agricultural fields, forests, meadows and wastelands occur in the vicinity of the mine. The closest surroundings of the water body are shown in Figure 1.

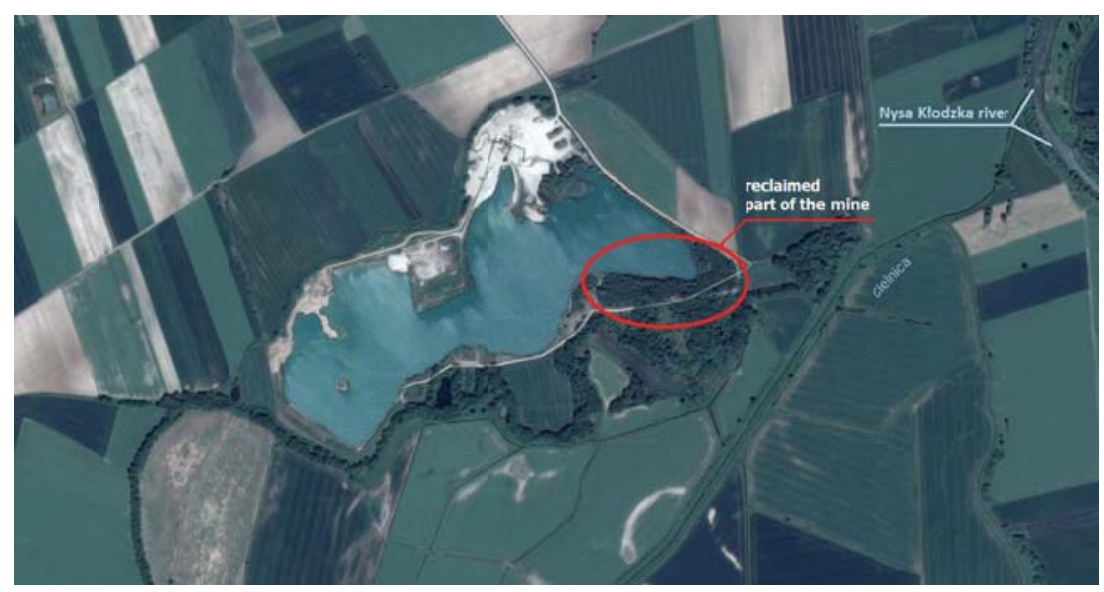

FIGURE 1. The immediate surroundings of the mine 
The south-eastern part of the reservoir was reclaimed in the forest direction and made available as fishery for recreation.

\section{METHODS}

The risk assessment performed in the paper was based on the elements of the common risk assessment methodology (CRAM), consisting of three stages of risk assessment: identification, analysis and assessment (Papathoma-Köhle et al. 2016). Risk identification first requires determining the context in which the risk criteria are located, then determining the types of hazards related to climate change - in this case extreme meteorological phenomena and determining elements of study area endangered with these phenomena. The next step is to analyse the risk consisting in determining the relative likelihood of the occurrence of a given phenomenon in the considered area and determining the relative impact of its consequences in relation to the previously selected elements of the mine. Relative likelihood were determined on the basis of meteorological data (IUNG, Meteoblue), maps (IMGW, KZGW), documents (Flood risk management plan... 2016, Rudkowski et al. 2016, Rybczyńska-Szewczyk et al. 2016), materials (Documentation of reclamation... 2015) and literature (Buchert et al. 2013, RCB 2013), while in determining of relative impact was considered: the degree of transformation of each mine element, spatial conditions and susceptibility to the effects of hazards resulting from individual features of elements (including: landlocked shape of water body, degree of soil compaction, species diversity and condition of plants and trees). It was assumed that due to the small surface of the analysed area, the relative likelihood of occurrence of a given hazard is the same for all endangered elements. However, the relative impact of a given hazard has been assigned individually to each element. These parameters form the risk matrix (Fig. 2), which determines the level of risk for individual elements. To make risk evaluation, the risk levels for hazards were averaged. At this stage,

Relative impact

\begin{tabular}{|c|c|c|c|c|c|}
\hline & 1 & 2 & 3 & 4 & 5 \\
\hline 5 & 5 & 10 & 15 & 20 & 25 \\
\hline 4 & 4 & 8 & 12 & 16 & 20 \\
\hline 3 & 3 & 6 & 9 & 12 & 15 \\
\hline 2 & 2 & 4 & 6 & 8 & 10 \\
\hline 1 & 1 & 2 & 3 & 4 & 5 \\
\hline \multirow[b]{2}{*}{ Rating } & 1 & 2 & 3 & 4 & 5 \\
\hline & $\begin{array}{l}\text { Very } \\
\text { low }\end{array}$ & Low & Medium & High & $\begin{array}{l}\text { Very } \\
\text { high }\end{array}$ \\
\hline
\end{tabular}

FIGURE 2. Risk matrix 
the hazards for which the level of risk should be reduced were indicated. Then, the elements of the analytic hierarchy process method (AHP) were used to determine the two most sensitive elements of the mine for which adaptive measures should be taken first. This method assumes that decision-making processes based on many criteria, including non-parametric criteria, are used to compare pairs of individual elements and create their hierarchy (Ostręga 2004). In this study, all elements of the mine were compared in pairs, and the following criteria were used: partial risk levels for individual mine elements related to hazards with an average level of risk higher than medium, as well as the ability to regenerate each element after the occurrence of these threats. The ability to regenerate was estimated by the author on the basis of field study and analysis of features and determinants of individual elements of the mine (including factors related to terrain and vegetation condition). The final stage of risk evaluation is the selection of actions aimed at reducing the risk level of two previously selected hazards and assessing the accuracy of selection of these activities. For this purpose, event tree analysis (ETA) was created for the case of occurrence heavy rainfall and of the occurrence of drought, taking into account the proposed reclamation measures, which are also actions aimed at adapting thhee most vulnerable elements to climate change thus reducing the level of risk. T research was elaborated on the basis of meteorological data analysis, analysis of documents and materials (including unpublished materials provided by the mine) and literature and field studies.

\section{RESULTS AND DISSCUTION}

\section{Risk identification}

Risk assessment was performed for a specific area, which is the post-mining area in an closed open-cast mine of rock raw materials. Over half of the area is a water reservoir created as a result of exploitation. In the identification of hazards, their impact on particular elements of the mine environment was taken into account, i.e. water body, trees, meadow, land without vegetation and grasses, as well as potential development directions. On the basis of a detailed analysis following hazards were identified:

- flood - the area is located on inundated land of Nysa Kłodzka;

- wildfire - associated mainly with the presence of anglers who leave trash, including increased amounts of glass bottles;

- strong wind - the mine is located in an open, flat space;

- heat wave - frequently occurring hot days in recent years in the region;

- drought - location in the area classified for the IV drought exposure group - strongly endangered (Rybczyńska-Szewczyk et al. 2016);

- heavy rainfall - especially dangerous for water body due to leaching of substances from arable fields and contaminated soil.

\section{Risk analysis}

For all threatened elements, the relative likelihood and relative impact of individual hazards was determined. For the purpose of further analysis, the risk level of each hazard was averaged. The results of risk analysis and the classification of risk levels are shown in the table. 
TABLE. Risk analysis

\begin{tabular}{|c|c|c|c|c|c|}
\hline Hazard & Element at risk & $\begin{array}{c}\text { Relative } \\
\text { likelihood }\end{array}$ & $\begin{array}{l}\text { Relative } \\
\text { impact }\end{array}$ & Risk level & $\begin{array}{c}\text { Average risk level } \\
\text { for hazard }\end{array}$ \\
\hline \multirow{5}{*}{ Flood } & water body & 1 & 5 & 5 & \multirow{5}{*}{4.6} \\
\hline & trees & 1 & 4 & 3 & \\
\hline & meadow & 1 & 5 & 5 & \\
\hline & $\begin{array}{l}\text { land without } \\
\text { vegetation }\end{array}$ & 1 & 4 & 3 & \\
\hline & grasses & 1 & 5 & 4 & \\
\hline \multirow{5}{*}{ Wildfire } & water body & 1 & 1 & 1 & \multirow{5}{*}{5.2} \\
\hline & trees & 3 & 4 & 12 & \\
\hline & meadow & 1 & 4 & 4 & \\
\hline & $\begin{array}{l}\text { land without } \\
\text { vegetation }\end{array}$ & 1 & 1 & 1 & \\
\hline & grasses & 4 & 2 & & \\
\hline \multirow{5}{*}{ Strong wind } & water body & 2 & 1 & 2 & \multirow{5}{*}{3.6} \\
\hline & trees & 2 & 3 & 6 & \\
\hline & meadow & 2 & 1 & 2 & \\
\hline & $\begin{array}{l}\text { land without } \\
\text { vegetation }\end{array}$ & 2 & 3 & 6 & \\
\hline & grasses & 2 & 1 & 2 & \\
\hline \multirow{5}{*}{ Heat wave } & water body & 2 & 4 & 8 & \multirow{5}{*}{5.6} \\
\hline & trees & 2 & 2 & 4 & \\
\hline & meadow & 2 & 3 & 6 & \\
\hline & $\begin{array}{l}\text { land without } \\
\text { vegetation }\end{array}$ & 2 & 2 & 4 & \\
\hline & grasses & 2 & 3 & 6 & \\
\hline & water body & 4 & 4 & 16 & \\
\hline & trees & 4 & 2 & 8 & \\
\hline Drought & meadow & 4 & 3 & 12 & 12.8 \\
\hline & $\begin{array}{l}\text { land without } \\
\text { vegetation }\end{array}$ & 4 & 3 & 12 & \\
\hline & grasses & 4 & 3 & 12 & \\
\hline & water body & 3 & 5 & 15 & \\
\hline & trees & 3 & 3 & 6 & \\
\hline Heavy & \begin{tabular}{|l|} 
meadow \\
\end{tabular} & 3 & 4 & 9 & 12 \\
\hline rainfall & $\begin{array}{l}\text { land without } \\
\text { vegetation }\end{array}$ & 3 & 4 & 12 & \\
\hline & grasses & 3 & 4 & 9 & \\
\hline & & Risk cl & fication & & \\
\hline$<6$ & $6-$ & & $10-15$ & & $>15$ \\
\hline low & med & & high & & very high \\
\hline
\end{tabular}




\section{Risk evaluation}

Risk analysis showed that the highest risk level applies to drought and heavy rainfall and it qualifies for high risk level, which means that actions should be taken to reduce the risk level to at least medium (Wróblewski et al. 2015). The scheme of determining two the most sensitive elements of the mine in relation to these hazards and the ability to regenerate after their occurrence has been shown in Figure 3. intense surface runoff. Drought can also intensify this negative effect, as it is often associated with high temperatures and high insolation in summer, which leads to heating up of the water body and the result of emergence of algal blooms (Pac 2012).

The second most vulnerable element is land without vegetation, which is an impermeable surface. In turn, this results in a high susceptibility to water erosion associated with surface runoff and hydrological

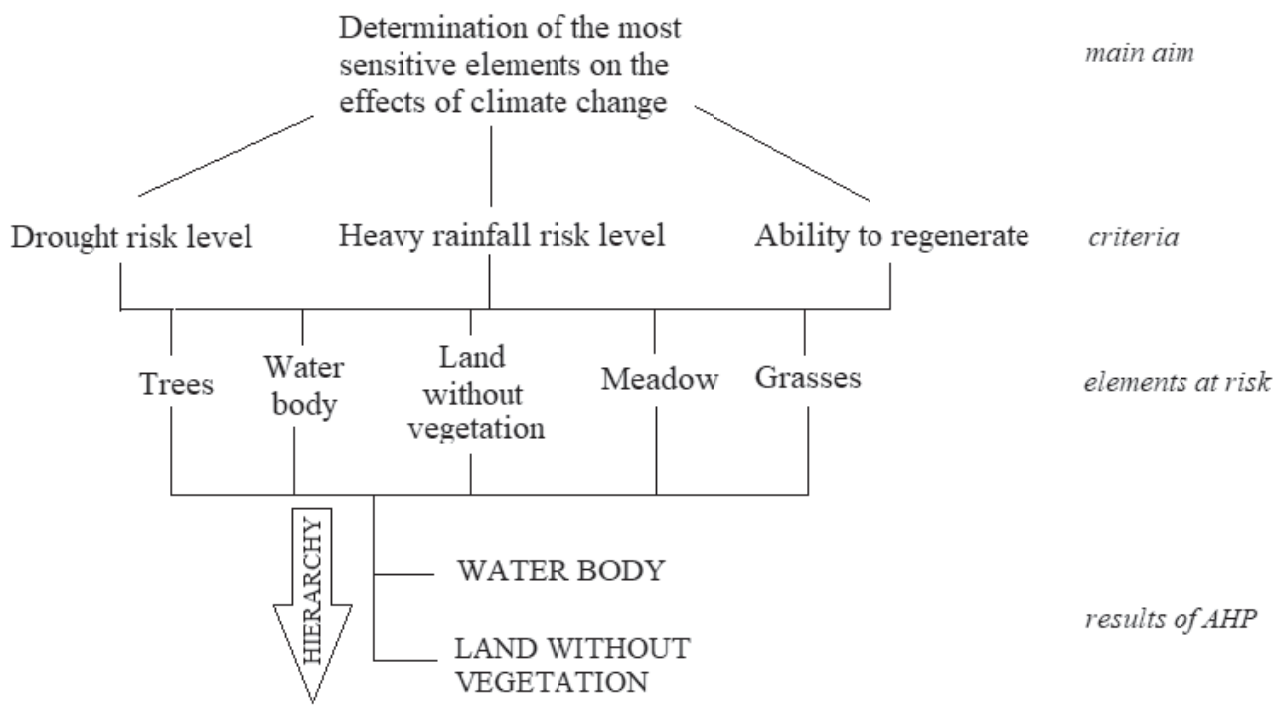

FIGURE 3. Schematic determination of the most vulnerable mine elements using AHP method

The most vulnerable element is water body. This is due to several factors - first of all it is a land-locked reservoir and therefore particularly exposed to degradation. Furthermore, the surrounding farmland is conducive to the ingress of biogens and other substances into it, which can lead to water algal blooming (Traczewska 2012). This effect may be compounded after the occurrence of heavy rainfall due to the appearance of erosion associated with land waterlogging or desiccation (Karczewska 2012).

As part of the reclamation process, as adaptation and reduction of risk related to drought and heavy rainfall, the following actions were selected:

- afforestation in land without reclamation;

- treatments aimed at securing and strengthening embankment - including planting them with vegetation; 
- shaping of surface in the direction of the drainage ditch;

- renovation of the drainage ditch separating arable land from the mine site;

- soil unsealing and increasing the share of biologically active area;

- special, small retention reservoirs designed for rainwater collection.

In order to verify the selection of activities, ETA for drought (Fig. 4) and heavy rainfall (Fig. 5) were made, taking into account the proposed adaptation measures. The effects of their application is marked in green. It can be observed that the proposed actions have a positive impact on limiting the effects of the occurrence of these extreme phenomena. In addition, activities such as afforestation or construction of small reservoirs retaining rainwater favourably affect both the mitigation of the effects of drought and heavy rainfall (Mioduszewski 2012) and indirectly on other hazards, between which there is a wide network of relationships and dependencies and very often they may coexist (Kaczmarczyk 2014).
Attention should be also paid to the consequences of not taking appropriate preventive measures, which in this case in the long term may lead to the degradation of the post-mining environment, and thus increase the level of risk associated with the occurrence of extreme meteorological phenomena. The necessity to verify the selection of adaptation measures and to consider the benefits as well as the difficulties and threats resulting from both the application and non-application of the considered actions as an integral part of risk assessment, are also indicated by Willows et al. (2003) and Jones and Preston (2010).

Reclamation of degraded areas is indicated as particularly important in the Strategic plan of adaptation for sectors and areas sensitive to climate change until 2020 with a view to 2030 (Strategic adaptation plan... 2012). The assessment of the risk of the impact of climate change on the post-mining area carried out in this article allowed for the precise selection of adaptive reclamation activi-

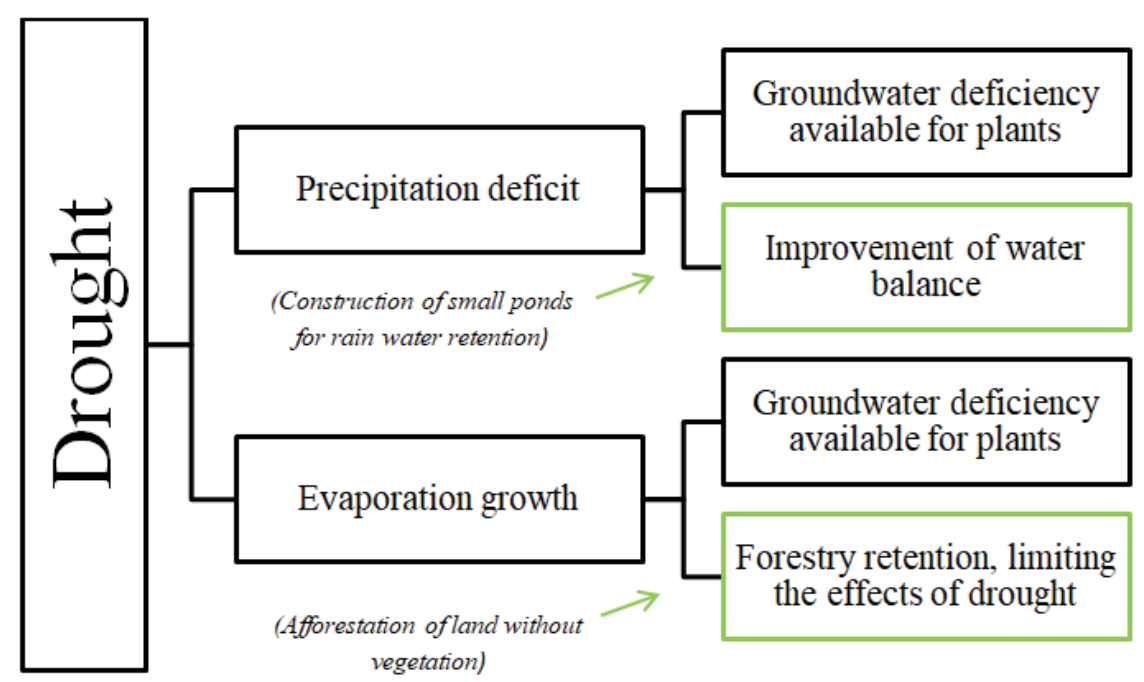

FIGURE 4. Event tree analysis for drought 


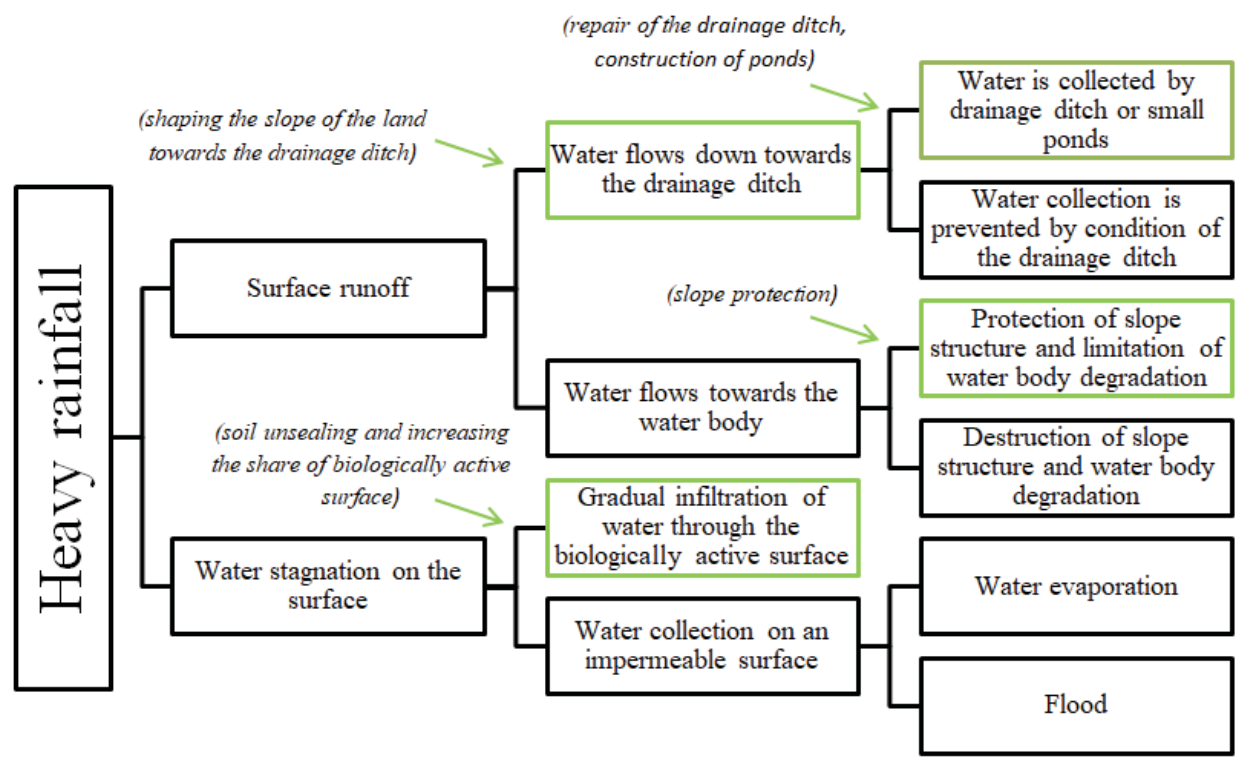

FIGURE 5. Event tree analysis for heavy rainfall

ties, which in practice may contribute to the proper implementation of climate policy, including SPA assumptions. Also Manson points out in his research that climate risk assessment is an integral part of designing adaptation activities (Manson et al. 2013).

\section{CONCLUSIONS}

The assessment of risk resulting from the occurrence of phenomena related to climate change allows identification of the risk level for the post-mining area. The assessment of this level helps to answer the question whether adaptation measures should be taken for a given type of hazard. In turn, the selection of the most vulnerable elements of the analyzed area using the AHP method helps to answer the question what specific measures should be taken to minimize the risk level in the most sensitive places, which will translate into a reduction of the risk level for the whole area. Subsequently, ETA for hazards with the highest level of risk allows to estimate the impact of proposed adaptation measures and the impact of partial or no action to reduce the negative impact of potential hazards.

It is not possible to completely eliminate the risk (Kundzewicz 2008), while it is extremely important to minimize its potential effects (Kundzewicz and Matczak 2010) already at the stage of reclamation work, which will reduce the negative impact of the phenomenon on the post-mining area and thus reduce the damage both in the economic and environmental, technical and social dimensions. Moreover, the risk assessment performed may also affect the selection or modification of the target development direction, if the identified hazard is related to the level of risk that excludes or significantly limits the given type of developing the post-mining area. 


\section{REFERENCES}

BUCHERT L., CEBULAK E., DRWAL-TYLMANN A., WOJTCZAK-GAGLIK E., KILAR P., LIMANÓWKA D., ŁAPIŃSKA E., MIZERA M., OGÓREK S., PYRC R., WINNICKI W., ZAWIŚLAK T. 2013: Vademecum niebezpieczne zjawiska meteorologiczne. Geneza, skutki, częstość występowania. Część pierwsza - wiosna, lato [Vademecum dangerous meteorological phenomena. Genesis, effects, incidence. Part one - spring, summer]. IMGW-PIB, Warszawa.

CAPSTICK S. 2016: Climate Change Impacts and Adaptation in the Mining Sector. Golder Associates. Retrieved from https://adaptationcanada2016.ca/wpcontent/uploads/2016/04/W1G-Capstick. pdf [presentation].

CHODAK M. 2013: Metody rekultywacji i zagospodarowania obszarów poeksploatacyjnych $\mathrm{w}$ górnictwie skalnym [Methods of reclamation and development of post-mining areas in rock mining]. Poltegor Instytut, Wrocław - Kraków.

Dokumentacja rekultywacji wyrobiska poeksploatacyjnego „Brzeziny” [Documentation of reclamation of the "Brzeziny" post-exploitation pit]. Niemodlin 2015 [unpublished].

European Commission, EC 2007: Green Paper from the Commission to the Council, the European Parliament, the European Economic and Social Committee and the Committee of the Regions. Adapting to climate change in Europe - options for EU action. Brussels 29.06.2007 [COM(2007) 354 final].

European Commission, EC 2013: Communication from the Commission of the European Parliament, the Council, the European Economic and Social Committee and the Committee Regions. An EU Strategy for adaptation to climate change. Brussels 16.04.2013 [COM(2013) 216 final].

FÜSSEL H.M. 2007: Adaptation planning for climate change: concepts, assessment approaches, and key lessons. Sustain. Sci. 2: 265-275.

IMGW: Mapy klimatu Polski [Climate maps of Poland]. Retrieved from http://klimat. pogodynka.pl/pl/climate-maps [accessed: 06.02.2018].

IUNG: System monitoringu suszy rolniczej [Agricultural drought monitoring system]. Retrieved from http://www.susza. iung.pulawy.pl [accessed: 05.02.2018].

JONES R.N., PRESTON B.L. 2010: Adaptation and risk management. Climate Change Working Paper 15. Centre for Strategic Economic Studies, Victoria University, Melbourne.

KACZMARCZYK B. 2014: Współczesny wymiar zagrożeń naturalnych [Contemporary dimension of natural hazards]. Kultura Bezpieczeństwa 15: 113-124.

KARCZEWSKA A. 2012: Ochrona gleb i rekultywacja terenów zdegradowanych [Soil protection and reclamation of degraded areas]. Wydawnictwo Uniwersytetu Wrocławskiego, Wrocław.

KUNDZEWICZ Z.W. 2008: Disaster Aftermath. In: H. Kirsch (Ed.). Encyclopedia of Public Health. Springer.

KUNDZEWICZ Z.W., MATCZAK P. 2010: Zagrożenia naturalnymi zdarzeniami ekstremalnymi [Natural disaster threats]. Nauka 4: 77-86.

KZGW: Mapy zagrożenia powodziowego i mapy ryzyka powodziowego [Flood hazard maps and flood risk maps]. Retrieved from http://mapy.isok.gov.pl/imap [accessed: 05.02.2018].

MANSON L., UNGER C., LEDERWASCH A., RAZIAN H., WYNNE L., GIURCO D. 2013: Adapting to climate risks and extreme weather: A guide for mining and minerals industry professionals. National Climate Change Adaptation Research Facility, Gold Coast.

Ministerstwo Środowiska, MŚ 2013a: Projekt KLIMADA „Opracowanie i wdrożenie strategicznego planu adaptacji dla sektorów i obszarów wrażliwych na zmiany klimatu": Konsekwencje zmian klimatu 
[KLIMADA project "Development and implementation of a strategic adaptation plan for sectors and areas sensitive to climate change": Consequences of climate change]. Retrieved from http://klimada. mos.gov.pl/zmiany-klimatu-w-polsce/ konsekwencje-zmian-klimatu [accessed: 26.02.2018].

Ministerstwo Srodowiska, MŚ 2013b: Strategiczny plan adaptacji dla sektorów i obszarów wrażliwych na zmiany klimatu do roku 2020 z perspektywą do roku 2030 [Strategic adaptation plan for sectors and areas sensitive to climate change by 2020 with a view to 2030]. Warszawa (wersja 23 z dn. 22.03.2013).

Meteoblue: Klimat Opole [Climate of Opole]. Retrieved from https://www.meteoblue.com/pl/pogoda/prognoza/modelclimate/opole polska 3090048 [accessed: 05.02.2018].

MIODUSZEWSKI W. 2012: Zjawiska ekstremalne w przyrodzie - susze i powodzie [Extreme phenomena in nature - droughts and floods]. In: A. Łachacz (Ed.). Wybrane problemy ochrony mokradeł. Wydawnictwo Uniwersytetu Warmińsko-Mazurskiego, Olsztyn.

OSTRĘGA A. 2004: Sposoby zagospodarowania wyrobisk i terenów po eksploatacji złóż surowców węglanowych na przykładzie Krzemionek Podgórskich w Krakowie [Methods of developing excavations and areas after mining of carbonate resources on the example of Krzemionki Podgórskie in Kraków]. Kraków.

PAC M. 2012: Sinice (Cyanobacteria) $\mathrm{w}$ środowisku słodkowodnym [Cyanobacteria in a freshwater environment]. Woda Środ. Obsz. Wiej. 12, 3 (39): 187-195.

PAPATHOMA-KÖHLE M., PROMPER C., GLADE T. 2016: A Common Methodology for Risk Assessmentand Mapping of Climate Change Related Hazards - Implications for Climate Change Adaptation Policies. Climate 4 (1): 8.

Plan zarządzania ryzykiem powodziowym dla obszaru dorzecza Odry (zał. do Roz- porządzenia Rady Ministrów z dnia 18 października 2016 r. w sprawie przyjęcia Planu zarządzania ryzykiem powodziowym dla obszaru dorzecza Odry) [Flood risk management plan for the Odra basin district (annex To the Regulation of the Council of Ministers of October 18, 2016 regarding the adoption of Flood risk management plan for the Odra river basin district)]. Dz.U. 2016, poz. 1938.

RCB 2013: Zagrożenia okresowe występujące w Polsce [Periodic hazards occurring in Poland]. Retrieved from http://rcb.gov.pl/wp-content/uploads/ RCB-Zagro\%C5\%BCenia-okresowew-Polsce-aktualizacja.pdf [accessed: 06.02.2018].

RUDKOWSKI B., BIL-KUBICKA I., ŻYREK E., JODŁOWSKA M. 2016: Plan gospodarki niskoemisyjnej dla gminy Skoroszyce [A low-emission economy plan for the Skoroszyce commune]. Skoroszyce.

RYBCZYŃSKA-SZEWCZYK M. et al. 2016: Analiza występowania zjawiska suszy oraz hierarchizacja i identyfikacja obszarów narażonych na występowanie skutków suszy na terenie administrowanym przez RZGW we Wrocławiu do Projektu Planu przeciwdziałania skutkom suszy w regionach wodnych Środkowej Odry, Izery, Metuje, Łaby i Ostrożnicy (Upa), Orlicy i Morawy [Analysis of drought occurrence and hierarchization and identification of areas exposed to the effects of drought in the area administered by RZGW in Wrocław to the Draft Plan for preventing the effects of drought in the Central Oder, Izera, Metuje, Elbe and Ostrożnica (Upa), Orlice and Morawy water regions]. RZGW we Wrocławiu, Warszawa.

TRACZEWSKAT.M. 2012: Problemy ekologiczne zbiorników retencyjnych w aspekcie ich wielofunkcyjności [Ecological problems of retention reservoirs in the aspect of their multifunctionality]. European Symposium Anti-flood Defences - Today's Problems, Paris - Orléans. 
Ustawa z dnia 3 lutego 1995 r. o ochronie gruntów rolnych i leśnych [Act on protection of agricultural and forest land]. Dz.U. $2004 \mathrm{nr} 121$, poz. 1266 z późn. zm.

Ustawa z dnia 9 czerwca 2011 r. prawo geologiczne i górnicze [Geological and mining law]. Dz.U. 2011 nr 163, poz. 981 $\mathrm{z}$ późn. $\mathrm{zm}$.

WILLOWS R., REYNARD N., MEADOWCROFT I., CONNELL R. 2003: Climate adaptation: Risk, uncertainty and decision-making. Part 2. UK Climate Impacts Programme, Oxford: 41-87.

WRÓBLEWSKI D., ABGAROWICZ G., ABGAROWICZ I., BANULSKA A., GOŁĘBIEWSKI J., GUZEWSKI P., KĘDZIERSKA M., MAŁOZIECĆ D., NAPIÓRKOWSKI M., POŁEĆ B., SKOMRA W., SOBÓR E., SOWA T., STĘPIEŃ P., TRZCIŃSKA M. 2015: Zarządzanie ryzykiem - przegląd wybranych metodyk [Risk management - an overview of selected methodologies]. CNBOP-PIB, Józefów: 86-88.

Streszczenie: Ocena ryzyka wptywu zmian klimatu na teren pogórniczy a jego rekultywacja na przyktadzie Kopalni Kruszywa Naturalnego „Brzeziny”. Łagodzenie zmian klimatu oraz adaptacja do ich skutków, przejawiających się w coraz częstszych i coraz bardziej gwałtownych ekstremalnych zjawiskach meteorologicznych, są jednymi z najważniejszych współczesnych światowych wyzwań. W obliczu nowych zagrożeń podejmuje się liczne działania mające na celu przystosowanie komponentów środowiska naturalnego i przedsięwzięć do zmian klimatu. Jednym z nich jest rekultywacja terenów zdegradowanych - uznawana za kluczowe działanie adaptacyjne i łagodzące. Powodzenie oraz właściwość doboru tych działań wymagają szczegółowego rozpoznania prawdopodobieństwa wystapienia poszczególnych zjawisk oraz określenia wagi ich następstw na danym terenie, a więc przeprowadzenia oceny ryzyka, która umożliwi właściwe zaprojektowanie przedsięwzięć adaptacyjnych. Co więcej odpowiednio przeprowadzona ocena ryzyka pozwala na identyfikację elementów najbardziej wrażliwych na zagrożenia związane ze zmianami klimatu, dla których adaptacja po- winna zostać podjęta w pierwszej kolejności. W pracy dokonano oceny ryzyka wpływu zmian klimatu na teren poeksploatacyjny i na podstawie jej wyników zaproponowano optymalny sposób rekultywacji żwirowni Brzeziny, mający na celu maksymalne przystosowanie jej do potencjalnych zdarzeń klimatycznych. Na terenie Kopalni Kruszyw Naturalnych „Brzeziny” znajduje się bezodpływowy zbiornik wodny o powierzchni lustra wody ok. 24 ha, powstały w wyniku prowadzenia eksploatacji odkrywkowej kruszyw metodą spod lustra wody. Ponadto duży udział w powierzchni żwirowni mają grunty pozbawione roślinności. Pozostałą niewielką część pokrywają zadrzewienia i roślinność trawiasta o małej wartości przyrodniczej oraz roślinność łąkowa. Najbliższe otoczenie kopalni stanowią pola uprawne, z których ze względu na ukształtowanie terenu wymywane są w kierunku wyrobiska nawozy i inne toksyczne substancje. Uwarunkowania te sprawiają, że bez podjęcia odpowiednio zaprojektowanej ( $\mathrm{tj}$. nastawionej również na adaptację) rekultywacji teren będzie podatny na negatywne konsekwencje zmian klimatu. Ocena ryzyka z wykorzystaniem metody CRAM (ang. common risk assessment methodology - metoda wspólnej oceny ryzyka) składa się z następujących etapów: identyfikacji ryzyka, analizy ryzyka oraz ewaluacji ryzyka. Do wyznaczenia komponentów kopalni, które są najbardziej wrażliwe na wystapienie ekstremalnych zjawisk meteorologicznych, zastosowano elementy metody AHP (ang. analytic hierarchy process - analityczny proces hierarchiczny) mającej na celu uproszczenie procesów decyzyjnych, w przypadku kiedy uwzględniają one wiele kryteriów, w tym kryteria nieparametryczne. Ponadto do oceny zaproponowanych działań adaptacyjnych na etapie rekultywacji została wykorzystana technika logiczna ETA (ang. event tree analysis - analiza drzewa zdarzeń), która umożliwia rozpatrzenie różnych scenariuszy, tj. zastosowania wskazanych działań, częściowego zastosowania lub niezastosowania żadnych działan.

Stowa kluczowe: ocena ryzyka zmian klimatycznych, rekultywacja, teren pogórniczy, adaptacja do zmian klimatycznych

MS received 10.02.2018

MS accepted 15.03.2018 


\section{Author's address:}

Katarzyna Pawełczyk

Katedra Górnictwa Odkrywkowego

Wydział Górnictwa i Geoinżynierii

AGH Akademia Górniczo-Hutnicza

al. Mickiewicza 30, 30-059 Kraków

Poland

e-mail: pawelczyk@agh.edu.pl 